\title{
PENELITIAN DAN PENGEMBANGAN E-MODULE GEOMETRI BERDASARKAN FASE PEMBELAJARAN GEOMETRI
}

\author{
Vina Muthmainna Rianto*, Punaji Setyosari, Sulton \\ Teknologi Pembelajaran, Fakultas IImu Pendidikan, Universitas Negeri Malang
}

\section{Edcomtech}

Jurnal Kajian Teknologi Pendidikan

Volume 6, No 2, Oktober 2021

288-300

DOI: $10.17977 /$ um039v6i12021p288

Submitted 02-12-2020

Accepted 29-01-2021

\section{Corresponding Author*}

Vina Muthmainna Rianto

Universitas Negeri Malang

Jl. Semarang No.5, Sumbersari, Kec. Lowokwaru, Kota Malang, Jawa

Timur 65145, Indonesia

Email: vinamuthmainna@gmail.com

\begin{abstract}
Abstrak
Pembelajaran geometri tidak terlepas dari fase pembelajaran geometri yang berlandaskan pada teori Van Hiele untuk meningkatkan level berpikir geometri pada siswa. E-module geometri yang disusun berdasarkan fase pembelajaran geometri berperan sebagai bahan ajar pada pembelajaran secara daring maupun luring. Penelitian ini bertujuan untuk mengembangkan e-module geometri khususnya pada materi segiempat dengan model pengembangan ADDIE oleh Branch. Subjek penelitian menggunakan siswa kelas VII SMP di Malang sebanyak 18 orang. Hasil pengembangan telah divalidasi oleh beberapa ahli dengan kategori sangat valid. Sedangkan efektivitas dari e-module geometri ditentukan dengan melihat nilai g yang mencapai angka 0.3 , yang menunjukkan bahwa emodule geometri cukup efektif pada peningkatan hasil belajar materi segiempat. Selain itu e-module dapat diimplementasikan pada proses pembelajaran baik di kelas maupun pembelajaran jarak jauh.

Kata Kunci: e-module, geometri, fase pembelajaran geometri
\end{abstract}

\begin{abstract}
The concept of learning geometry is based on phases of learning geometry, by Van Hiele, which enhances about students' levels of geometric thinking. Drafting geometry e-module based on phases of learning geometry becomes one of the teaching materials and has a role in online and offline learning. This study focuses on developing a geometry e-module, on quadrilaterals. The development model used ADDIE by Branch. The research is participated by 18 students of grade VII in secondary school in Malang. The product has been validated by experts, which were perfectly valid. Meanwhile, the effect of the emodule is determined by looking at the gain score, was 0.3 , which indicates that geometry e-module is quite effective in enhancing learning outcomes of quadrilaterals and implemented in classroom or distance learning.
\end{abstract}

Keywords: e-module, geometry, phases of learning geometry 


\section{LATAR BELAKANG}

Generasi abad 21 identik dengan perkembangan teknologi yang berdampak pada pola kehidupan manusia, dimulai dari lingkungan kerja yang memerlukan komputer, serta teknologi lain yang mempercepat suatu aktivitas dalam kehidupan. Hal ini juga berpengaruh pada bidang ilmu pengetahuan khususnya dalam bidang pendidikan. Teknologi dan media mengalami penyesuaian dan dalam proses perancangannya diperlukan agar dapat membantu siswa sebagai pebelajar secara efektif dalam proses pengajaran. (Smaldino et al., 2011). Apalagi pengaruh teknologi pada abad 21 merupakan hasil adaptasi dari generasi sebelumnya yaitu abad 20, yang mana disebut sebagai peristiwa "singularitas", peristiwa yang terjadi ketika kedatangan dan penyebaran secara cepat terutama pada 10 tahun terakhir pada abad 20 (Prensky, 2001).

Berkaitan dengan perkembangan abad 21, perkembangan tidak hanya muncul pada sektor teknologi, namun juga kompetensi dan keterampilan pada siswa yang menjadi digital natives. Istilah tersebut mengacu pada orang yang menjadi penutur asli bahasa digital dari computer, video games, dan internet (Prensky, 2001) atau secara singkat dikatakan sebagai orang yang lahir saat teknologi sudah ada di lingkungannya. Kompetensi yang diperlukan menurut Assessment and Teaching of 21st Century Skills yaitu cara berpikir, cara bertindak, kesadaran dalam mengembangkan hidup maupun karir, dan keterampilan beradaptasi dengan dunia baru seperti teknologi atau jaringan (Griffin et al., 2012). Pada generasi ini menuntut seseorang untuk memiliki kompetensi tersebut. Hal ini diperlukan agar dapat melalui persaingan ketat pada abad 21, yang mana telah berbeda jauh dengan 20 atau 30 tahun silam (Zubaidah, 2016).

Pengembangan kompetensi tersebut menjadikan teknologi dalam pembelajaran semakin unik dan menimbulkan banyak inovasi. Inovasi tersebut memunculkan pengalaman belajar baru di dalam proses pembelajaran sebagai perantara dalam menyampaikan isi setiap pelajaran pada jenjang tertentu. Satu diantara contoh inovasi tersebut adalah berkembangnya model pembelajaran kreatif disertai dengan bahan ajar yang tepat. Dalam hal ini, peran guru sangat diperlukan, mengingat prinsip pembelajaran di abad 21 yang sesuai dengan kompetensi tersebut menerapkan pembelajaran aktif, saling berkolaborasi, kontekstual, dan terintegrasi dengan masyarakat (Zubaidah, 2016).

Konten pembelajaran pada bahan ajar juga meluas hingga hampir ke semua cabang ilmu, khususnya mata pelajaran di sekolah, apalagi jika berhadapan dengan mata pelajaran yang dikategorikan sulit untuk dipahami, seperti pelajaran matematika. Selain tuntutan kompetensi abad 21 yang telah dipaparkan, kesulitan lain terlihat pada tujuan pembelajaran matematika yang harus dicapai pada jenjang pendidikan dasar dan menengah. Tujuan tersebut terdiri dari: 1) memahami konsep matematika, 2) menggunakan pola sebagai dugaan dalam penyelesaian masalah dan mampu membuat generalisasi berdasarkan fenomena atau data yang ada, 3) menggunakan penalaran sifat, melakukan manipulasi matematika baik dalam penyederhanaan, maupun menganalisa komponen yang ada dalam pemecahan masalah dalam konteks matematika maupun di luar matematika 4) mengkomunikasikan gagasan, penalaran serta mampu menyusun bukti matematika, dan 5) memiliki sikap dan menghargai kegunaan matematika dalam kehidupan (Kemendikbud, 2014). Tujuan tersebut juga selaras dengan standar proses pembelajaran matematika yang tertulis dalam buku NCTM (National Council of Teachers of Mathematics) yang terdiri dari kemampuan pemecahan masalah, penalaran dan bukti, komunikasi, koneksi dan representasi (Midgett \& Eddins, 2001). Namun pembahasan tersebut belum dapat menyajikan hal terkait geometri. 
Geometri adalah satu diantara cabang matematika yang berhubungan dengan angka dan bentuk. Pemahaman tentang materi ini memiliki hasil representasi berupa bantuan untuk siswa dalam memahami materi matematika lain seperti pecahan dan perkalian aritmatika, hubungan pada grafik fungsi untuk 2 atau 3 variabel, memahami data yang tersaji pada materi statistika (Jones, 2002). Geometri dikategorikan sebagai pokok bahasan yang cukup sulit serta mengikuti pendekatan penalaran deduktif. Hal ini menjadikan mayoritas siswa merasa bahwa materi ini menjadi materi yang sulit dipahami dan tidak disukai (Connolly, 2010). Menurut van Hiele, salah satu penyebab kesulitan dalam memahami geometri juga terdapat pada cara pikir guru dan siswa yang berbeda. Saat menyampaikan materi geometri, guru melakukan pendekatan dari berbagai sisi seperti menghubungkan dengan beberapa teorema, namun berbeda dengan siswa yang berpikir dengan cara menghafal (Fuys et al., 1984). Hal ini juga didukung oleh beberapa studi sebelumnya yang mengungkapkan bahwa secara umum siswa menghafal rumusnya tanpa memahami konsep-konsep geometri (Cahyaningrum, 2016). Adapun permasalahan lain yaitu kebingungan yang melanda beberapa siswa dalam mencari luas bangun datar terutama luas gabungan bangun datar juga tidak lepas dari kesulitan pembelajaran geometri (Indrayany \& Lestari, 2019).

Kesulitan terjadi karena beberapa kondisi yaitu internal dan eksternal (Hanafi, 2017). Kondisi internal terjadi pada setiap individu yang memunculkan perbedaan tingkat pemahaman dalam pembelajaran. Kondisi eksternal terjadi ketika metode pengajaran yang belum tepat serta referensi tentang materi geometri. Berdasarkan hasil wawancara pada Guru Matematika kelas VII di SMPN 15 Malang, siswa tergolong aktif dalam berbagai aktivitas yang terjadi di sekolah. Namun saat proses pembelajaran, khususnya pada pelajaran Matematika, siswa tergolong malas membaca. Penerapan e-module dalam pembelajaran Matematika belum pernah dilakukan dan masih menerapkan pembelajaran konvensional yang dibarengi dengan kegiatan praktik. Guru telah menyadari metode pembelajaran yang tepat untuk siswa, namun kurangnya fasilitas pendukung pembelajaran yang menyebabkan sulitnya menerapkan pengalaman belajar yang baru.

Untuk memudahkan proses pembelajaran geometri di sekolah, terlebih dahulu siswa harus memahami alur berpikir geometri. Alur tersebut mengacu pada teori Van Hiele yang berisi tentang beberapa tingkatan berpikir geometri. tingkatan tersebut dikelompokkan menjadi lima tingkatan yaitu: (1) Visualization (Visualisasi), (2) Analysis (Analisis), Abstraction (Abstraksi), (4) Deduction (Deduksi), (5) Rigor (Keakuratan). Sehingga dalam proses pembelajaran geometri itu sendiri tidak terlepas dari teori Van Hiele (Musser et al., 2013).

Teori Van Hiele tidak hanya membicarakan tentang tahapan berpikir geometri. Ketika menggunakan tahapan berpikir geometri, maka setiap kemajuan dari satu tahapan ke tahapan lain tergantung pada kesiapan siswa sebagai pebelajar dan lebih dominan tergantung pada proses dari pembelajaran (Ismail, 2009). Dalam hal ini, peran guru sangat membantu dalam pembelajaran geometri itu sendiri. Seiring berjalannya proses pembelajaran geometri yang berkolaborasi dengan teori Van Hiele, penyesuaian tersebut membentuk fase pembelajaran geometri. Fase pembelajaran geometri yang terbentuk adalah informasi, orientasi, penjelasan, orientasi bebas, dan integrasi (Purwoko, 2009). Implementasi dari fase ini dominan memberikan hasil yang positif. Berdasarkan hasil penelitian yang diujikan kepada siswa tingkat SMP di Malaysia, penerapan fase pembelajaran geometri Van Hiele di kelas menjadi solusi untuk membantu siswa dalam meningkatkan level berpikir 
geometri (Abdullah \& Zakaria, 2013a). Penelitian lain yang menerapkan fase ini yaitu dengan menggunakan media tangram. Hal ini juga mendapatkan hasil positif, dimana membantu siswa dalam mencapai tingkat pemikiran geometris lebih baik dan perlu diterapkan pada proses pembelajaran di sekolah (Siew et al., 2013). Peningkatan prestasi belajar geometri diperoleh ketika diberikan perangkat pembelajaran geometri yang terintegrasi oleh teori Van Hiele (Musdi \& Gusnita, 2018). Beberapa penelitian tersebut mendukung bahwa penerapan fase pembelajaran geometri dapat mengurangi miskonsepsi geometri terhadap siswa serta meningkatkan level berpikir geometri siswa.

Implementasi dari fase

pembelajaran geometri pada proses pembelajaran memiliki beberapa cara. Salah satunya yaitu pengembangan bahan ajar berupa e-module. E-module yang dikhususkan dalam pembelajaran geometri diharapkan dapat menjadi solusi untuk pembelajaran yang menarik. Emodule yang dikembangkan berbasis $e$ learning (electronic Learning) yang merupakan salah satu pembelajaran yang menggunakan media elektronik seperti komputer dan internet. manfaat yang bisa dirasakan yaitu e-module dapat dilihat di luar pembelajaran di kelas dengan memanfaatkan teknologi dan internet. Namun jarang ditemui e-module geometri yang sesuai dengan teori belajar Van Hiele.

Terdapat satu contoh modul pembelajaran segiempat dengan konten yang berdasarkan teori Van Hiele. Hal yang membedakan modul sebelumnya dengan e-module geometri yang dikembangkan saat ini adalah e-module tidak hanya disajikan secara tertulis, namun terdapat animasi visual sederhana dari beberapa bangun yang membantu siswa dalam memahami materi. Dengan tampilan yang menarik, maka diharapkan e-module geometri dapat mengatasi kesulitan dalam belajar geometri. Selain itu, penelitian mengungkap bahwa perbedaan hasil belajar yang signifikan terjadi ketika diberikan $e$ module dan buku panduan cetak dimana pemberian e-module lebih efektif (Astalini et al., 2019). Hasil studi lain mengenai penggunaan modul geometri yang berbasis teori Van Hiele yaitu peningkatan level berpikir geometri siswa sebanyak $45 \%$ siswa dalam satu populasi menjadikan modul dinilai efektif (Argaswari, 2018). Selain itu penelitian lain mengungkap bahwa penerapan fase pembelajaran geometri menjadi mudah dan lebih efektif jika dibantu dengan teknologi (Abdullah \& Zakaria, 2012). Oleh karena latar belakang tersebut maka peneliti tertarik dalam mengembangkan e-module geometri berdasarkan fase pembelajaran geometri pada materi segiempat.

\section{METODE}

\section{Prosedur Pengembangan}

Model pengembangan yang digunakan adalah model pengembangan ADDIE menurut Branch. Model ADDIE merupakan model pengembangan yang berfokus pada pembuatan bahan ajar dalam proses pembelajaran yang kompleks (Branch, 2009). Model ini menggunakan 5 tahap pengembangan yang tertera pada Gambar 1.

\section{Teknik Analisis Data}

Tujuan pengembangan yaitu mengembangkan e-module geometri yang valid dan efektif. Dengan memperhatikan tujuan tersebut, diperlukan data kuantitatif dan kualitatif yang dilakukan pengolahan dan analisis. Sumber data untuk data kuantitatif

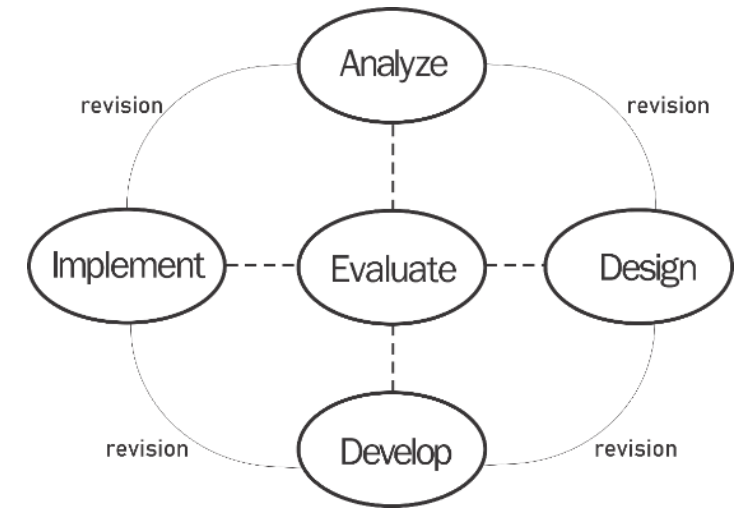

Gambar 1. Model ADDIE Menurut Branch 
menggunakan instrumen penelitian yaitu lembar validasi dan soal pre dan posttest, sedangkan untuk sumber data untuk data kualitatif diperoleh dari kritik dan saran validator serta siswa sebagai pengguna.

Sasaran penelitian yaitu siswa kelas VII SMP yang sedang mempelajari materi Segiempat pada semester genap. Siswa kelas VII yang terpilih sebagai subjek penelitian sebanyak 18 siswa kelas VII C SMP Negeri 15 Malang sekaligus masuk dalam 1 kelompok besar pada penelitian. Sebelum produk diujikan kepada kelompok besar, produk terlebih dahulu divalidasi oleh beberapa ahli serta siswa yang tergabung pada kelompok kecil, yaitu siswa kelas VII A dan kelas VII B di sekolah yang sama berjumlah masing-masing 2 siswa. Untuk mencapai tujuan pengembangan, maka perlu menganalisis validitas e-module geometri baik dari segi konten/materi maupun media. Proses validasi menggunakan lembar validasi yang ditujukan kepada ahli konten/materi dan media. Data hasil validasi dihitung menjadi persentase skor dengan rumus persentase (1) sebagai berikut.

$$
\mathrm{V}(\%)=\frac{\text { Skor yang diperoleh }}{\text { Skor maksimal }} \text { Xasil } \text { akhir dari } \mathrm{V}(\%)
$$

diinterpretasikan dengan mengikuti tabel konversi yang telah dimodifikasi sebagaimana pada tabel 1 . Seperti yang telah dipaparkan sebelumnya mengenai sasaran penelitian, yaitu satu kelas, maka desain uji coba yang digunakan yaitu preexperimental berbentuk one-group pretest-posttest design. Gambaran desain penelitian sebagai berikut (Sugiyono, 2019).

Tabel 1. Konversi Validitas

\begin{tabular}{cc}
\hline Persentase & Keterangan \\
\hline$\geq 80,01 \%$ & Sangat valid \\
$60,01 \%-80,00 \%$ & Cukup valid \\
$40,01 \%-60,00 \%$ & Kurang valid \\
$\leq 40,00 \%$ & Tidak valid \\
\hline
\end{tabular}

(Sumber: Akbar, 2013)
Tabel 2. Desain Penelitian

\begin{tabular}{cccc}
\hline Subjek & Pretest & Perlakuan & Posttest \\
\hline $\begin{array}{c}\text { Siswa } \\
\text { Kelas }\end{array}$ & $\mathrm{O}_{1}$ & $\mathrm{X}$ & $\mathrm{O}_{2}$ \\
VII C & & \\
\hline \multicolumn{3}{c}{ Tabel 3. } & Kriteria Nilai $\boldsymbol{g}$ \\
\hline \multicolumn{3}{c}{$g$} & Kriteria \\
\hline \multicolumn{2}{c}{$g \geq 0.7$} & Tinggi \\
$0.7>g \geq 0.3$ & Sedang \\
$g<0.3$ & Rendah \\
\hline
\end{tabular}

(Sumber: Hake, 1998)

Sedangkan keefektifan e-module diperoleh dari hasil nilai pre dan posttest pada kelompok besar. Untuk melihat efektivitas dari e-module geometri, teknik analisis yang digunakan yaitu dengan melihat gain score (Hake, 1998) yang menggunakan data tes pre dan post siswa. Rumus (1) yang digunakan yaitu:

$$
\boldsymbol{g}=\frac{\%\langle\text { Nilai Posttest }\rangle-\%\langle\text { Nilai Pretest }\rangle}{100-\%\langle\text { Pretest }\rangle}
$$

Hasil dari $\boldsymbol{g}$ diinterpretasikan dengan mengikuti tabel kriteria nilai $\boldsymbol{g}$ pada tabel 3.

\section{HASIL PENGEMBANGAN}

Hasil pengembangan yang dibahas terlebih dahulu adalah tampilan e-module geometri. tampilan ini berisi tampilan isi, daftar sub materi, navigasi, serta sistematika pre dan posttest. Adapun tampilan rancangan konten terdapat pada gambar 2. Pembahasan selanjutnya adalah hasil validasi. E-module divalidasi oleh beberapa praktisi yaitu satu orang ahli konten dan satu orang ahli media. Beberapa siswa turut menjadi penilai sekaligus pengguna e-module. Siswa yang menjadi partisipan yaitu siswa kelas VII SMP Negeri 15 Malang yang tergabung dalam kelompok kecil dan kelompok besar.

Bagian yang perlu divalidasi adalah bagian konten dan media. Dalam memvalidasi konten/materi pada e-module geometri, maka diperlukan ahli materi yang berkaitan dengan bidang Matematika. Sedangkan pada media, diperlukan ahli media yang berkaitan dengan teknologi pendidikan. Hasil validasi disajikan pada Tabel 4. Hasil pada Tabel 4 membawa keputusan untuk melanjutkan ke uji coba lapangan atau uji coba kelompok besar. Uji coba kelompok besar dilakukan dengan meng 

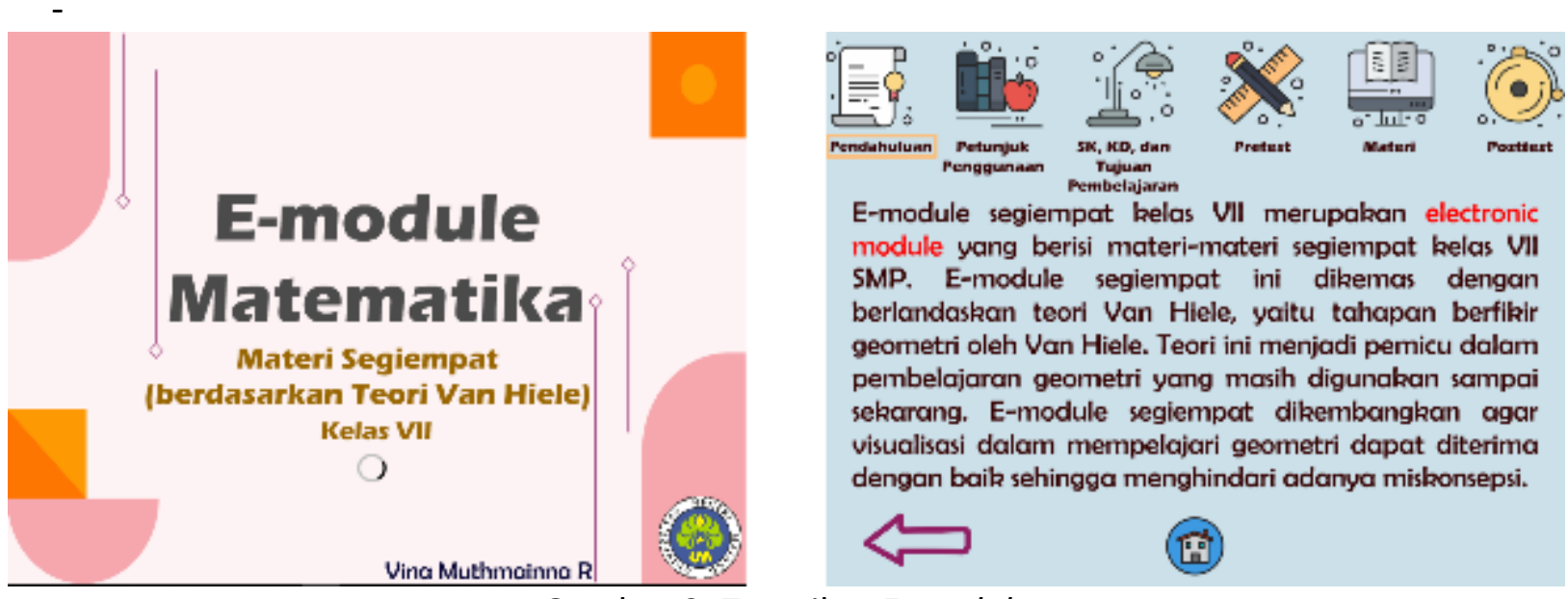

E-module segiempat kelas VII merupakan electronic module yang berisi materi-materi segiempat kelas VII SMP. E-module segiempat ini dikemas dengan berlandaskan teori Van Hiele, yaitu tahapan berfikir geometri oleh Van Hiele. Teori ini menjadi pernicu dalam pembelajaran geometri yang masih digunakan sampai sekarang. E-module segiempat dikembangkan agar visualisasi dalam mempelajari geometri dapat diterima dengan baik sehingga menghindari adanya miskonsepsi.
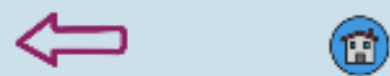

Gambar 2. Tampilan E-module

Tabel 4. Hasil Validasi

\begin{tabular}{|c|c|c|c|}
\hline Praktisi & Skor & Persentase & Ket \\
\hline $\begin{array}{c}\text { Ahli } \\
\text { Konten }\end{array}$ & 112 & $82,97 \%$ & $\begin{array}{c}\text { Sangat } \\
\text { Valid }\end{array}$ \\
\hline $\begin{array}{c}\text { Ahli } \\
\text { Media }\end{array}$ & 239 & $99,59 \%$ & $\begin{array}{c}\text { Sangat } \\
\text { Valid }\end{array}$ \\
\hline
\end{tabular}

Tabel 5. Nilai Pre dan Posttest

\begin{tabular}{ccc}
\hline Siswa & Pre & Post \\
\hline 1 & 48,33 & 55,33 \\
2 & 46 & 44,33 \\
3 & 35 & 0 \\
4 & 0 & 62,33 \\
5 & 30,67 & 35 \\
6 & 56 & 59,33 \\
7 & 42,67 & 51 \\
8 & 0 & 79,67 \\
9 & 0 & 32,33 \\
10 & 0 & 32 \\
11 & 66 & 71,67 \\
12 & 0 & 62,33 \\
13 & 48,67 & 53,33 \\
14 & 0 & 30 \\
15 & 0 & 30,33 \\
16 & 0 & 52 \\
17 & 73,33 & 75 \\
18 & 68,67 & 75,33 \\
\hline Rerata & $\mathbf{2 8 , 6 3}$ & $\mathbf{5 0 , 0 7}$ \\
& $\left\langle\boldsymbol{S}_{\boldsymbol{f}}\right\rangle$ & $\left\langle\boldsymbol{S}_{\boldsymbol{i}}\right\rangle$ \\
\hline
\end{tabular}

Dalam penelitian ini kita menggunakan rumus (1) untuk menghitung nilai $\boldsymbol{g}$

$$
\boldsymbol{g}=\frac{\%\left\langle\boldsymbol{S}_{\boldsymbol{f}}\right\rangle-\%\left\langle\boldsymbol{S}_{\boldsymbol{i}}\right\rangle}{\mathbf{1 0 0 - \%} \%\left\langle\boldsymbol{S}_{\boldsymbol{i}}\right\rangle}
$$

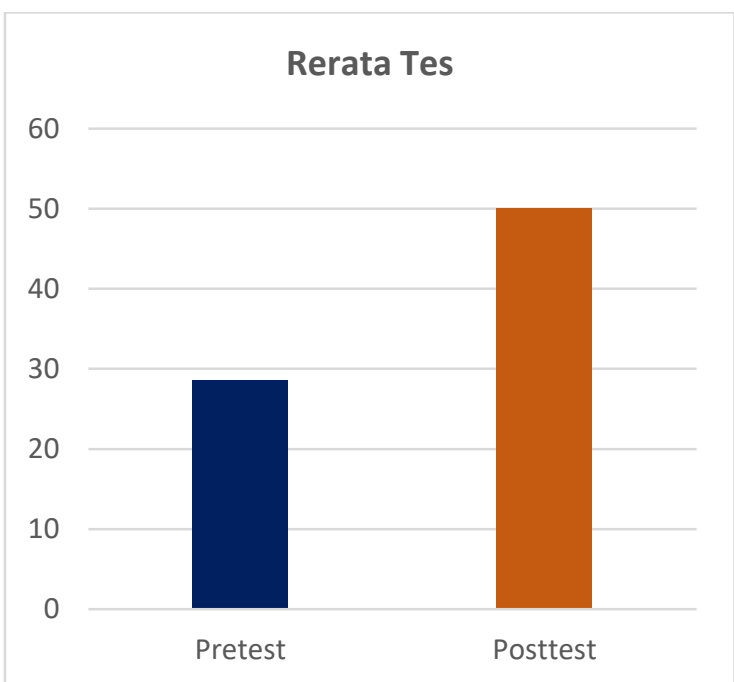

Gambar 3. Diagram Rerata Tes Pre dan Post

-implementasikan penggunaan e-module geometri pada proses pembelajaran berlangsung, yaitu saat materi Segiempat dipelajari di kelas. Sebelum maupun setelah diberikan e-module, terdapat tes awal dan tes akhir untuk melihat efektivitas e-module. Efektivitas ditentukan dengan melihat Gain Score $(g)$ yang diperoleh dari hasil tes keseluruhan siswa kelompok besar. Tabel 5 berisi data hasil tes siswa beserta perhitungan Gain score $(g)$.

$$
\begin{aligned}
& =\frac{50,07-28,63}{100-28,63} \\
& \approx \mathbf{0 , 3}
\end{aligned}
$$




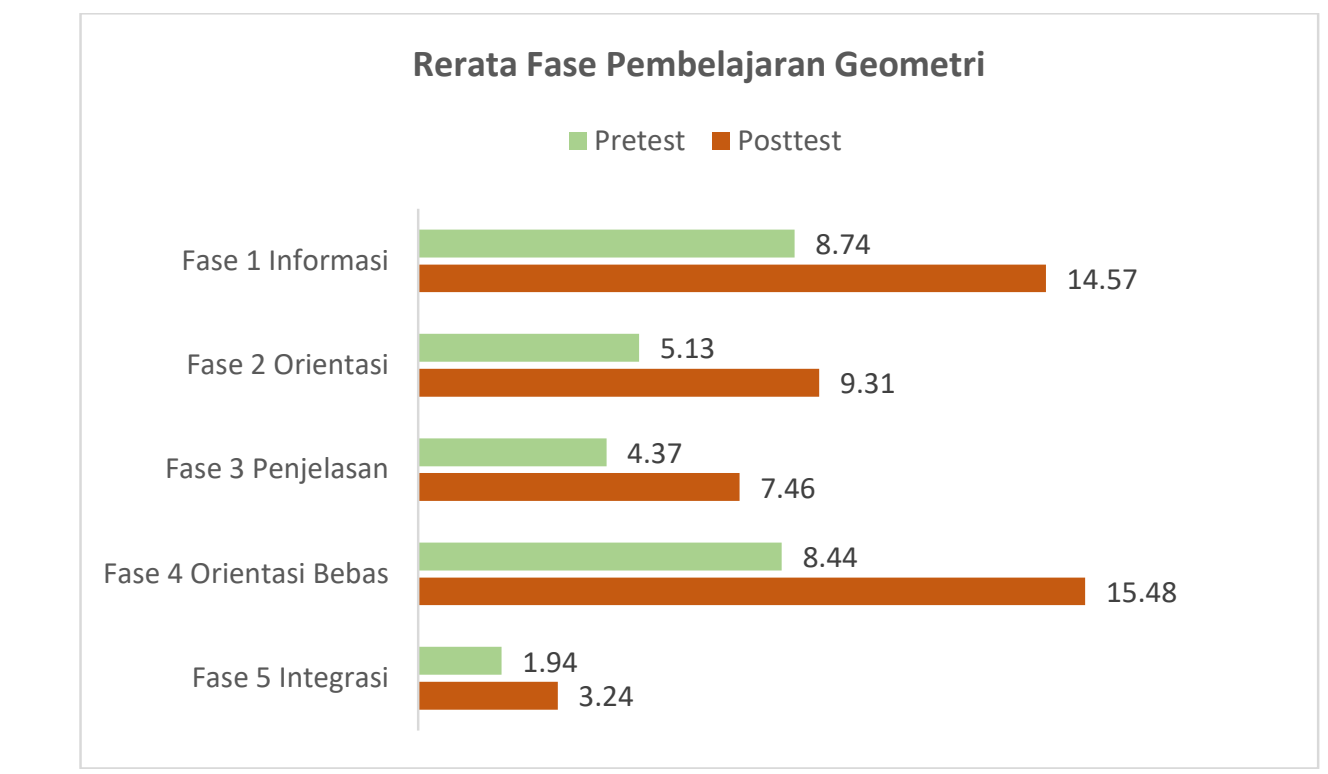

\section{Gambar 4. Diagram Rerata Fase Pembelajaran Geometri}

Hasil $\boldsymbol{g}$ diperoleh sebesar $\mathbf{0 , 3}$. Berdasarkan interpretasi gain score pada Tabel 3, hasil $g$ masuk dalam kriteria sedang. Selanjutnya, hasil belajar dari sebelum dan sesudah diberikan e-module geometri tidak hanya berpengaruh pada nilai dari tes, namun juga pada setiap fase pembelajaran geometri. Berikut merupakan diagram rerata setiap fase berdasarkan tes pre dan post siswa.

\section{PEMBAHASAN}

Pengembangan

e-module

geometri memiliki tujuan akhir yaitu menjadi e-module yang valid dan efektif. Untuk mencapai tujuan tersebut, maka $e$ module geometri perlu diuji sehingga dapat menjadi satu diantara bahan ajar yang siap untuk digunakan baik untuk pembelajaran matematika di kelas, maupun pembelajaran yang menerapkan sistem daring atau PJJ (Pembelajaran Jarak Jauh). Proses pengembangan memperhatikan tahapan pengembangan yang mana menggunakan model pengembangan ADDIE menurut Branch, (2009) yang ditunjukkan pada Gambar 1.

Tahapan pertama yaitu menganalisis (Analyze). Tahap ini tidak hanya mencakup analisis kesenjangan atau kebutuhan, namun banyak faktor seperti penentuan tujuan pembelajaran, mengkonfirmasi sasaran penelitian mengidentifikasi kebutuhan yang diperlukan dalam pengembangan, cara penyampaian produk, serta menyusun time schedule (rencana pelaksanaan).

Dalam melihat analisis kebutuhan dapat menggunakan observasi dan wawancara kepada guru (Dick et al., 2015). Dari hasil observasi dan wawancara, siswa mengikuti proses pembelajaran seperti metode ceramah, atau menonton video pembelajaran. pemberikan e-module belum pernah diberikan mengingat belum adanya bahan ajar berupa $e$ module. Dengan kondisi siswa yang tergolong malas dalam membaca buku teks, e-module geometri menjadi solusi bagi siswa dalam pembelajaran. penyusunan e-module geometri memperhatikan penyu-sunan modul dengan bahasa yang komunikatif sehingga dapat terjadi proses pembelajaran mandiri (Depdiknas, 2008). Sasaran pada pengembangan e-module geometri yaitu siswa kelas VII SMP Negeri 15 Malang yang berada di jenjang semester genap khususnya sedang menempuh materi Segi Empat. Dalam mengidentifikasi kebutuhan, terdapat beberapa aspek yaitu konten, teknologi, fasilitas, dan sumber daya (Branch, 2009). Beberapa kebutuhan yang diperlukan pada pengembangan e-module geometri yaitu pada konten berupa buku teks dan modul matematika, pada teknologi berupa aplikasi 
yang mengembangkan program e-module yaitu Adobe Animate CC 2019 dan beberapa aplikasi desain grafis seperti Adobe Photoshop CC 2018 dan GeoGebra Classic, pada fasilitas yaitu sistem penyampaian pembelajaran e-module kepada siswa dengan menggunakan Meet sebagai video call conference, dan sumber daya berupa sasaran pengembangan yaitu siswa kelas VII. Dalam mengakses $e$ module geometri, diperlukan perangkat berupa smartphone pada setiap siswa. sebelum mengakses e-module, siswa wajib memasang aplikasi e-module pada perangkat masing-masing sesuai dengan tutorial pemasangan yang diberikan sebelumnya. Implementasi pengembangan e-module dilakukan pada bulan Mei 2020 secara daring.

Tahap kedua yaitu mendesain (Design). Dalam tahap ini, hal yang perlu diperhatikan yaitu membuat daftar komponen isi e-module secara umum, menentukan tujuan pelaksanaan, dan merencanakan uji coba. Daftar komponen yang menjadi isi e-module mencakup sub materi yang terpilih menjadi konten yaitu materi Segiempat, dan tampilan seperti ukuran scene, jenis tulisan (font), serta ukuran font. Pada pembuatan komponen isi juga mencakup susunan tampilan konten pada e-module. Pelaksanaan pengembangan e-module diharapkan dapat meningkatkan daya pikir siswa terhadap pembelajaran geometri dengan sumber data yang diperoleh merupakan hasil belajar siswa pada pembelajaran geometri, khususnya segiempat. Setelah memperhatikan desain secara umum, maka selanjutnya e-module siap untuk diuji coba. Sebelum uji coba, e-module perlu divalidasi dengan melibatkan beberapa ahli seperti ahli konten dan ahli media. Persiapan instrumen penelitian lain yaitu angket respon untuk melihat kepraktisan serta soal pre dan posttest untuk melihat keefektifan.
Setelah mendesain secara umum, tahap selanjutnya yaitu mengembangkan (Develop). Perancangan konten ke dalam emodule, pemilihan media pendukung, penyusunan petunjuk penggunaan, serta revisi formatif merupakan beberapa hal yang menjadi komponen pada tahap ini. Dalam penyusunan e-module mengikuti penyusunan modul yang sesuai dengan Depdiknas tahun 2008. Tahap Develop juga memperhatikan ketersediaan petunjuk penggunaan e-module. Petunjuk penggunaan terdapat 2 jenis, yaitu petunjuk saat memasang (install) e-module geometri dan petunjuk saat mengakses $e$ module. Pada petunjuk penggunaan saat memasang e-module menggunakan video tutorial dan diunggah pada grup obrolan pada kelas VII C yang menjadi sasaran penelitian. Gambaran umum pada video tutorial adalah siswa diminta untuk mengunduh Meet sebagai media untuk melakukan video call conference dengan kondisi internet dalam keadaan ON. Selanjutnya yaitu siswa diberikan link unduh $e$ module geometri agar dapat dipasang pada perangkat smartphone masing-masing untuk kemudian diakses saat proses pembelajaran secara daring berlangsung. Dalam pemasangan aplikasi e-module, pengembang turut berpartisipasi dalam mengontrol dan mengawasi sehingga jika terdapat masalah dapat segera teratasi. Sedangkan pada petunjuk saat menggunakan e-module geometri terdapat pada menu di e-module. Petunjuk penggunaan berfungsi agar siswa tidak bingung saat melihat beberapa menu yang perlu dipilih terlebih dahulu.

Selain itu, tahapan ini juga mengatur tentang perencanaan dalam revisi formatif maupun uji coba lapangan. Dalam revisi formatif bertujuan untuk menguji e-module dari segi valid dan praktis sebelum diimplementasikan pada uji coba lapangan. Proses ini melibatkan siswa kelas VII diluar kelas VII C yang tergabung dalam kelompok kecil sebanyak 4 orang. Pengujian validitas dilakukan oleh beberapa ahli yaitu ahli konten dan ahli media. 
Struktur konten atau materi sangat diperlukan dalam penyusunan e-module. Penyusunan konten memperhatikan cara pengorganisasian materi, kedalaman materi, kebenaran konsep materi, kemutakhiran materi, dan penyesuaian dengan fase pembelajaran geometri. Materi yang telah diidentifikasi baik itu merujuk pada subjek pelajaran maupun berdasarkan individu yang belajar akan membantu bila memuat struktur konten yang sistematis (Depdiknas, 2008). Penyajian materi di dalam e-module menekankan visual gambar segiempat dan konsep umum serta transformasi bangun datar seperti simetri putar. Penyajian gambar memiliki banyak fungsi, diantaranya yaitu menarik perhatian atas materi yang disampaikan (attentional functions), membawa emosi siswa menjadi lebih santai (affective functions), memfasilitasi informasi atau penjelasan dalam belajar (cognitive functions), serta menjadi bantuan yang efektif bagi siswa yang mengalami kesulitan dalam memahami suatu penjelasan (compensatory functions) (Levie \& Lentz, 1982). Dengan memper-hatikan fungsi tersebut, pembelajaran materi segiempat dengan perpaduan media yang berbasis visual diharapkan dapat mudah dipahami. Media seperti ini dapat memudahkan pemahaman dan dalam mengingat, yang mana sangat diperlukan dalam proses pembelajaran (Arsyad, 2009).

Dengan mengikuti kaidah penyajian modul, penggunaan e-module dapat dipahami oleh siswa serta mendukung fungsi dan peran modul yaitu pembelajaran mandiri. Hal ini didukung dengan hasil analisis validasi ahli konten yang mengukur struktur konten pada $e$ module mendapatkan persentase sebesar 82,97\% dengan interpretasi pada Tabel 1 dikategorikan sangat valid. Hasil tersebut menunjukkan bahwa e-module geometri yang tersusun sesuai dengan struktur mata pelajaran sehingga dapat menjadi panduan belajar segiempat yang memudahkan siswa. Interpretasi lain yaitu penyesuaian antara media dengan konten pelajaran. Pada saat media, materi/ konten, dan gaya berpikir siswa memiliki kecocokan, maka pembelajaran memiliki kemungkinan besar untuk dipahami (Clark \& Salomon, 2011).

E-module dievaluasi berdasarkan kelayakan atau kevalidan media oleh ahli media. Hasil analisis pada validasi ahli media menunjukkan persentase sebesar 99,59\% dengan interpretasi yang sesuai pada Tabel 1 dikategorikan sangat valid, atau disimpulkan bahwa secara media maupun penyusunan modul telah dikembangkan secara valid dan $e$ module dapat diimplementasikan pada proses pembelajaran. Secara umum, lembar validasi ahli media berisi tentang penyusunan dan kelengkapan e-module, menyesuaikan $e$ module dengan format atau karakteristiknya, penyajian e-module serta penyajian berdasarkan teori atau fase pembelajaran geometri. Adapun karakteristik dari e-module mengikuti karakteristik modul yaitu self instructional (dapat membelajarkan diri sendiri), self contained (memuat materi dalam satu unit secara utuh), stand alone (berdiri sendiri), adaptive (memiliki daya adaptif tinggi), dan user friendly (bersahabat dengan pemakai) (Depdiknas, 2008). Dari hasil analisis revisi formatif berupa validasi konten dan validasi media membawa keputusan untuk melanjutkan ke uji coba lapangan atau uji coba kelompok besar. Pertimbangan hasil pada tahap Develop menjadi penentu untuk melangkah ke tahapan selanjutnya yaitu tahap Implement.

Proses pada tahap Implement secara umum adalah mengimplementasikan produk yang dikembangkan dalam proses pembelajaran sekaligus menjadi kegiatan uji coba lapangan. Pada pengembangan ini, proses pembelajaran menggunakan Meet sebagai media untuk pembelajaran jarak jauh. Pada tahap ini diikuti oleh siswa yang tergabung dalam kelompok besar yaitu siswa kelas VII C SMP Negeri Malang berjumlah 18 orang. Proses implementasi secara umum yaitu siswa 
diberikan tutorial pemasangan aplikasi $e$ module geometri yang bernama $E$-module Segiempat serta link unduh. Sebelum melihat e-module, siswa diminta untuk menguji kemampuan dasar masingmasing dengan pemberian tes awal (pretest) dan dikontrol menggunakan Meet. Setelah selesai tes awal, siswa dipersilahkan untuk mengakses $E$-module Segiempat yang telah dipasang. Proses diakhiri dengan tes akhir sebagai tes untuk menguji sejauh mana pemahaman siswa setelah diberikan e-module.

Tahap terakhir adalah tahap Evaluate (mengevaluasi). Setelah $e$ module geometri diimplementasikan pada pembelajaran, dilakukan evaluasi untuk melihat keefektifan e-module dengan cara memberikan pre dan posttest. Proses pada tahap ini secara umum telah dijabarkan pada tahap Implement sebelumnya. Efektifitas ditentukan dengan melihat Gain Score $(g)$ yang diperoleh dari hasil pre dan posttest dari keseluruhan siswa. hasil gain score diperoleh sebesar 0,3 . Berdasarkan interpretasi gain score pada Tabel 2 sebelumnya, hasil $g$ masuk dalam kriteria sedang. Maksud dari kriteria sedang adalah e-module cukup efektif dalam meningkatkan hasil belajar siswa. Hasil ini juga didukung dengan hasil tes siswa yang cukup meningkat dari pre ke posttest (Gambar 7).

Selanjutnya adalah pembahasan mengenai hasil tes dilihat dari fase pembelajaran geometri. Untuk melihat efektifitas e-module sekaligus perkembangan level berpikir geometri siswa, siswa diberikan tes yang mana indikator setiap butir soal memuat setiap fase pembelajaran geometri.

Pada Tabel 5 menyajikan data hasil tes yang mana siswa mengalami perubahan nilai. Jika dilihat pada kolom pre (sebelum diberikan e-module) dan post (setelah diberikan e-module), nilai siswa mengalami kenaikan. Selain kenaikan pada hasil tes, rerata setiap fase berdasarkan pre dan post juga mengalami kenaikan yang positif (Gambar 8). Kenaikan tersebut menunjukkan bahwa fase pembelajaran geometri berpengaruh secara positif dalam meningkatkan berpikir geometris dan hasil belajar siswa. Hal ini sesuai dengan penelitian sebelumnya mengenai penggunaan modul pada materi geometri yang terintegrasi dengan teori Van Hiele efektif dalam meningkatkan level berpikir geometri (Argaswari, 2018). Penelitian lain yang mendukung yaitu implementasi dari aktivitas yang terintegrasi dengan fase pembelajaran geometri memiliki dampak positif terhadap perkembangan level berpikir geometri (Abdullah \& Zakaria, 2013b). Pemberian media khususnya e-module juga berdampak positif dalam meningkatkan hasil belajar geometri. Berdasarkan hasil penelitian sebelumnya bahwa penggunaan media pada pembelajaran geometri yang terintegrasi dengan teori Van Hiele memiliki peningkatan hasil belajar geometri siswa (Sutama et al., 2014). Dengan melihat beberapa hasil penelitian tersebut, dapat ditarik kesimpulan bahwa pemberian $e$ module geometri yang dikembangkan pada siswa dapat membe-rikan peningkatan level berpikir geometri serta daya retensi mengenai materi Segiempat meningkat.

Daya retensi siswa yang meningkat mengenai materi geometri, khususnya Segiempat juga dipengaruhi oleh beberapa faktor. Penggunaan e-module geometri sebagai media pembelajaran berperan penting dalam memberikan pemahaman terhadap suatu konsep Segiempat. Media khususnya media pembelajaran menjadi bantuan bagi siswa dalam memahami konsep yang mungkin sulit dijelaskan dengan bahasa pengajaran (bahasa verbal) (Rusman, 2017). Selain itu, penerapan fase pembelajaran geometri juga menjadi pola penyajian yang tepat dalam membelajarkan geometri. Fase yang diterapkan oleh pengajar atau guru dengan gaya mengajarnya sendiri pada program pembelajaran menjadikan fase tersebut sebagai pola dalam merencanakan atau menyajikan materi geometri, sehingga efek dari pengajaran tersebut berdampak pada 
keaktifan siswa dalam berpartisipasi (Dongwi, 2014).

E-module geometri tidak terlepas dari revisi, baik dari praktisi konten dan media, maupun siswa sebagai pengguna. Saran dari ahli konten berupa penambahan suara dan mematikan fungsi tombol agar e-module tidak mudah keluar secara otomatis. E-module geometri sengaja tidak diberikan suara agar siswa dapat fokus dalam belajar. untuk mematikan fungsi tombol diperlukan bahasa pemrograman yang rumit. Pertimbangan ini dapat digunakan sebagai saran untuk penelitian selanjutnya. Sedangkan dari ahli media, e-module geometri dapat dilanjutkan pada penelitian selanjutnya.

Siswa sebagai pengguna juga diberikan kesempatan untuk memberikan penilaian mengenai e-module geometri. Komentar dan saran memiliki kolom tersendiri sehingga dapat melihat tanggapan siswa secara kualitatif. Beberapa siswa cenderung merasa bahwa e-module geometri sangat praktis karena dapat diakses pada pada perangkat smartphone dan dapat digunakan di luar pembelajaran di sekolah. hal itu memberikan efek positif pada diri siswa dalam memahami materi geometri. Pembelajaran yang menggunakan multimedia, seperti e-module, berdampak pada penyimpanan informasi, pemecahan masalah, dan pengiriman informasi yang positif. Hal ini disebabkan pada multimedia berisi konten yang bersifat kreatif serta meningkatkan representasi terhadap suatu materi. Dalam hal ini juga memunculkan berbagai macam cara dalam memperoleh informasi dan meningkatkan kemampuan kognitif (Graesser et al., 2011).

\section{SIMPULAN}

Pemanfaatan teknologi dalam
pendidikan menjadi kemajuan positif
untuk mencerdaskan anak bangsa.

Pemanfaatan tersebut seharusnya diimbangi dengan akses oleh pengguna yang tidak terbatas. Salah satu contoh pemanfaatan teknologi dalam bidang pendidikan adalah adanya pengembangan e-module. Setelah menganalisis kebutuhan yang juga dialami oleh guru dan siswa, hal ini menjadikan alasan peneliti ingin mengembangkan e-module geometri yang berdasarkan fase pembelajaran geometri.

Penelitian ini bertujuan mengembangkan e-module geometri dengan materi khusus segiempat. Dengan mempertimbangkan hasil validasi, dan keefektifan penggunaan, e-module geometri yang dikembangkan tervalidasi oleh beberapa praktisi dan cukup efektif dalam meningkatkan hasil belajar, daya retensi serta level berpikir geometri siswa. Dalam penggunaannya, $e-$ module dapat diberikan pada saat pembelajaran di kelas, maupun pada sistem PJJ (Pembelajaran Jarak Jauh), sehingga siswa dapat mengulang materi yang telah disampaikan pada pembelajaran geometri, khususnya pada materi segiempat.

Pengembangan e-module geometri tidak terlepas dari beberapa saran pengembangan. Pengunggahan ke Google Play Store menjadi saran yang cukup utama pada penelitian selanjutnya agar dapat diunduh dengan mudah oleh semua kalangan. Dari segi konten atau materi, perlunya ditambahkan materi geometri lain selain segiempat. Hal ini bertujuan untuk memberikan penjelasan secara rinci bahwa materi geometri sangat luas.

\section{REFERENSI}

Abdullah, A. H., \& Zakaria, E. (2012). The Activities Based on Van Hiele's PhaseBased Learning: Experts' and Preservice Teachers' Views. Journal of Mathematics and Statistics, 8(3), 385-395. https://doi.org/10.3844/jmssp.2012.385 .395

Abdullah, A. H., \& Zakaria, E. (2013a). Enhancing Students' Level of Geometric Thinking Through Van Hiele's Phase-based Learning. Indian Journal of Science and 
Technology, 6(5), 1-15. https://doi.org/10.17485/ijst/2013/ v6i5.13

Abdullah, A. H., \& Zakaria, E. (2013b). The Effects of Van Hiele's Phases of Learning Geometry on Students' Degree of Acquisition of Van Hiele Levels. Procedia - Social and Behavioral Sciences, 102, 251-266. https://doi.org/10.1016/j.sbspro.20 13.10 .740

Akbar, S. (2013). Instrumen Perangkat Pembelajaran. PT Remaja Rosdakarya.

Argaswari, D. P. A. D. (2018). Penelitian dan Pengembangan Modul Pembelajaran Geometri Berbasis Teori Van Hiele. HISTOGRAM: Jurnal Pendidikan Matematika, 2(2), 108119.

https://doi.org/10.31100/histogram .v2i2.211

Arsyad. (2009). Media Pembelajaran. PT Grafindo Persada.

Astalini, A., Darmaji, D., Kurniawan, W., Anwar, K., \& Kurniawan, D. A. (2019). Effectivenes of Using EModule and E-Assessment. International Journal of Interactive Mobile Technologies (IJIM), 13(09), 21-39.

https://doi.org/10.3991/ijim.v13i09 .11016

Branch, R. M. (2009). Instructional Design: The ADDIE Approach. Springer US. https://doi.org/10.1007/978-0-38709506-6

Cahyaningrum, A. O. (2016). Analisis Kesulitan Menyelesaikan Soal Geometri Ditinjau Dari Level Berpikir. Publikasi Ilmiah, 10. http://v2.eprints.ums.ac.id/archive/ etd $/ 44619 / 2 / 4$

Clark, R. E., \& Salomon, G. (2011). Media Theory. In R. C. Richey, J. D. Klein, \& M. W. Tracey (Eds.), The Instructional Design Knowledge Base: Theory, Research, and Practice (pp. 84-101). Routledge.
Connolly, S. (2010). The Impact of van Hielebased Geometry Instruction on Student Understanding. St. John Fisher College.

Depdiknas. (2008). Penulisan Modul. Direktorat Tenaga Kependidikan Direktorat Jenderal Peningkatan Mutu Pendidik dan Tenaga Kependidikan Departemen Pendidikan Nasional.

Dick, W., Carey, L., \& Carey, J. O. (2015). The Systematic Design of Instruction (Eighth edition). Pearson.

Dongwi, B. L. (2014). Using the Van Hiele Phases of Instruction to Inform the Design and Implementation of a Circle Geometry Teaching and Learning Programme. In Namibia Counts: Mathematics Education Research in Namibia (pp. 107-119). Digital Print Solutions. https://www.researchgate.net/publicati on/333647851

Fuys, D. J., Geddes, D., \& Tischler, R. W. (1984). English Translation of Selected Writings of Dina van Hiele-Geldof and Pierre $M$. van Hiele. ERIC.

Graesser, A. C., Chipman, P., \& King, B. G. (2011). Media Theory. In R. C. Richey, J. D. Klein, \& M. W. Tracey (Eds.), The Instructional Design Knowledge Base: Theory, Research, and Practice (pp. 84-101). Routledge.

Griffin, P., McGaw, B., \& Care, E. (2012). Assessment and Teaching of 21st Century Skills. Springer.

Hake, R. R. (1998). Interactive-Engagement Versus Traditional Methods: A SixThousand-Student Survey of Mechanics Test Data for Introductory Physics Course. American Journal of Physics, 66(1), 64-74. https://doi.org/10.1119/1.18809

Hanafi, M. A. (2017). Deskripsi Kesulitan Belajar Geometri Mahasiswa Program Studi Pendidikan Matematika Fakultas Keguruan dan Ilmu Pendidikan Universitas Cokroaminoto Palopo. Prosiding Seminar Nasional, 3, 273-283. http://journal.uncp.ac.id/index.php/proc eeding/article/view/797

Indrayany, E. S., \& Lestari, F. (2019). Analisis Kesulitan Siswa SMP Dalam Memecahkan 
Masalah Geometri Dan Faktor Penyebab Kesulitan Siswa Ditinjau Dari Teori Van Hiele. Jurnal Math Educator Nusantara: Wahana Publikasi Karya Tulis IImiah di Bidang Pendidikan Matematika, 5(2), 109123.

https://doi.org/10.29407/jmen.v5i2 .13729

Ismail. (2009). Fase-Fase Pembelajaran Geometri. In Purwoko (Ed.), Teori Belajar Van Hiele. Konsorsium PJJ S1 PGSD.

Jones, K. (2002). Issues in the Teaching and Learning of Geometry. In L. Haggarty (Ed.), Aspects of Teaching Secondary Mathematics: Perspectives on practice (pp. 121-139). RoutledgeFalmer.

Kemendikbud. (2014). Peraturan Menteri Pendidikan dan Kebudayaan, Nomor 58, Tahun 2014, tentang Kurikulum 2013 Sekolah Menengah Pertama (SMP) / Madrasah Tsanawiyah (MTS).

Levie, W. H., \& Lentz, R. (1982). Effects of Text Illustrations: A Review of Research. Educational Communication and Technology: $A$ Journal of Theory, Research, and Development, 30(4), 195-232.

Midgett, C. W., \& Eddins, S. K. (2001). NCTM's Principles and Standards for School Mathematics: Implications for Administrators. NASSP Bulletin, 85(623), 35-42. https://doi.org/10.1177/019263650 108562305

Musdi, E., \& Gusnita, N. (2018). Development of Mathematical Learning Devices Using Van Hiele Theory in Geometry of The Students In Grade VIII Secondary High School. Proceedings of the 2nd International Conference on Mathematics and Mathematics Education 2018
(ICM2E 2018), 54-57.

https://doi.org/10.2991/icm2e-

18.2018.14

Musser, G. L., Burger, W. F., \& Peterson, B. E. (2013). Mathematics for Elementary Teachers (8th ed.). John Wiley \& Sons, Inc.

Prensky, M. (2001). Digital Natives, Digital Immigrants Part 1. On the Horizon, 9(5), 1-6.

https://doi.org/10.1108/1074812011042 4816

Purwoko. (2009). Teori Belajar Van Hiele. In Elang K (Ed.), Paket Bahan Ajar PJJ S1 PGSD. Direktorat Jendral Pendidikan Tinggi.

Rusman. (2017). Belajar dan Pembelajaran Berorientasi Standar Proses Pendidikan. Prenadamedia Group.

Siew, N. M., Chong, C. L., \& Abdullah, M. R. (2013). Facilitating Students' Geometric Thinking Through Van Hiele's PhaseBased Learning Using Tangram. Journal of Social Sciences, 9(3), 101-111. https://doi.org/10.3844/jsssp.2013.101. 111

Smaldino, S. E., Lowther, D. L., \& Russel, J. D. (2011). Teknologi Pembelajaran dan Media untuk Belajar (A. Rahman, Trans.). Prenadamedia Group.

Sugiyono. (2019). Metode Penelitian Pendidikan. Alfabeta.

Sutama, I. K., Suharta, I. G. P., \& Suweken, G. (2014). Pengembangan Perangkat Pembelajaran Geometri SMA Berdasarkan Teori Van Hiele Berbantuan Wingeom Dalam Upaya Meningkatkan Aktivitas dan Hasil Belajar Siswa. Jurnal Pendidikan dan Pembelajaran Matematika Indonesia, 3(1), 1-14.

Zubaidah, S. (2016). Keterampilan Abad Ke-21: Keterampilan yang Diajarkan Melalui Pembelajaran. Seminar Nasional Pendidikan dengan Tema "Isu-Isu Strategis Pembelajaran MIPA Abad 21", 21, 2-3. 